\title{
Features of YAG crystals growth by the Czochralski method in Mo crucibles
}

\author{
P.Arhipov, S.Tkachenko, S.Vasyukov, M.Biatov, O.Sidletskiy, \\ P.Mateychenko*, E.Bryleva* \\ Institute for Scintillation Materials, STC "Institute for Single Crystals" \\ National Academy of Sciences of Ukraine, 60 Lenin Ave., 61001 Kharkiv, \\ Ukraine \\ "Institute for Single Crystals, National Academy of Sciences of Ukraine, \\ 60 Lenin Ave., 61001 Kharkiv, Ukraine
}

\section{Received July 30, 2014}

\begin{abstract}
Results on growth of $\mathrm{Y}_{3} \mathrm{Al}_{5} \mathrm{O}_{12}$ (YAG) crystals by the Czochralski method in Mo crucibles in reducing and oxidizing atmosphere are presented. The ways to improve the growth technology for obtaining of high quality crystals are determined. The factors providing reduction of absorption in UV-band are discussed, as well as post-growth annealing regimes aimed at elimination of these absorption bands.
\end{abstract}

Приведены результаты по выращиванию кристаллов $\mathrm{Y}_{3} \mathrm{Al}_{5} \mathrm{O}_{12}$ (YAG) из $\mathrm{MO}$ тиглей в восстановительной и слабо окислительной среде. Определены пути улучшения технологии выращивания для получения качественных кристаллов YAG. Обсуждаются факторы, позволяющие снизить интенсивность полос поглощения кристаллов в УФ-диапазоне, отработаны режимы термообработки для устранения этих полос.

Особливості вирощування кристалів YAG методом Чохральського з Мо тиглів. П.Архипов, С.Ткаченко, С.Васюков, М.Біатов, О.Сілецький, П.Матейченко, К.Брильова.

Наведено результати з вирощування кристалів YAG з Мо тиглів у відновлювальному та слабо окислювальному середовищі. Визначені шляхи покращення технології вирощування для отримання якісних кристалів YAG. Обговорюються чинники, що дозволяють знизити інтенсивність смуг поглинання у УФ діапазоні, відпрацьовано режими термообробки для усунення цих смуг.

\section{Introduction}

$\mathrm{Y}_{3} \mathrm{Al}_{5} \mathrm{O}_{12}$ (YAG) is a well-known host material for production of laser and scintillation elements. YAG is basically grown by the Czochralski (Cz) [1], temperature gradient technique (TGT) [2], and horizontal directional crystallization (HDC) methods [3]. The growth is carried out in Ir crucibles in inert atmosphere, or in Mo crucibles in vacuum, or in weakly reducing atmosphere. Usage of Mo crucibles is a way to reduce crystal production cost, because they are significantly cheaper and have longer lifetime compared to the Ir crucibles.

There are numerous reports on growth of YAG crystals by the Czochralski method starting from 1960th [4-8]. Nevertheless, some recently published works $[9,10]$ indicates that some peculiarities of the processes taking place at growth and postgrowth annealing of YAG crystals remain unknown. In particular, this relates to the nature and methods of elimination of absorption in UV-band.

Control of growth atmosphere composition is the crucial factor determining the 
quality of crystals grown in Mo crucibles. Oxygen concentration in the growth atmosphere is of particular importance, because molybdenum oxide may dissolve in the melt and be captured by the growing crystal. Presence of $\mathrm{CO}$ in the atmosphere called by utilization of graphite parts in thermal construction is another crucial factor. Interaction of $\mathrm{CO}$ with the melt containing uncontrolled admixtures may lead to shift of the melt composition, as well as to formation of carbides and oxygen vacancies [5].

YAG crystals were grown in Mo crucibles in the different atmospheres. The growth atmospheres were $\mathrm{Ar}+\mathrm{H}_{2}$ [1], $\mathrm{Ar}+\mathrm{CO}$ [2]; $\mathrm{Ar}+\mathrm{CO}+\mathrm{H}_{2}$ [3]. Growth of YAG by the TGT method [1] was carried out in the Mo crucible in Ar atmosphere using graphite heater. Reducing atmosphere (CO) is formed during growth process by interaction of carbon with residual oxygen and products of the melt dissociation. Quality of the YAG:Ce crystals grown by the TGT method in Mo crucible and by the $\mathrm{Cz}$ method in Ir crucible was analyzed in [2]. The growth atmosphere was reducing in the first case and weakly oxidizing in the second case. Differences in the growth conditions affects optical absorption spectra and termoluminescence properties of the crystals. The differences in optical properties were attributed to elevated concentration of the lattice defects.

The crystals grown in vacuum demonstrate good optical characteristics [3]. Meanwhile, there is a danger of thermal dissociation of alumina and the melt evaporation. The melt losses may reach $1-5 \%$. Also, the melt dissociation leads to shift of its composition and formation of perovskite phase $\mathrm{YAIO}_{3}$ inclusions [3]. Products of the dissociation also interact with thermal construction elements and crucible with formation of volatile oxides and carbides (if carbon heat insulation is used). The conditions and issues of Mo interaction with YAG and alumina melt dissociation products in vacuum and protective atmosphere are analyzed in details in $[11,12]$. Therefore, utilization of the reducing atmosphere is preferable to sustain the stable growth process.

Under growth in protective atmospheres the more stringent requirements should be applied to purity of the used gases. Oxygen even with concentration of $0.1 \mathrm{~mol} \%$ may lead to formation of molybdenum oxide, gas transport reactions, contamination of the melt and formation of precipitates at the thermal construction elements.
YAG absorption spectrum contains 300 and $370 \mathrm{~nm}$ absorption spectra attributed to iron ions [2]. In [1] YAG coloration, and wide absorption band at 470 was linked to the melt non-stoichiometry and the presence of Mo admixture. The effect of iron ions was excluded by the prolonged holding of the melt. The peaks at 255 and $370 \mathrm{~nm}$ were attributed to the presence of $F$-centers [3].

This work is focused at optimization of the crystal growth from Mo crucibles and the post-growth annealing procedures of YAG crystals.

\section{Experimental}

YAG crystals were grown from the Mo crucible with diameter $85 \mathrm{~mm}$ and height $85 \mathrm{~mm}$ by the $\mathrm{Cz}$ method using RF heating with $8 \mathrm{kHz}$ frequency. The thermal insulation consisted of alumina ceramics, zircon ceramics and graphite layers. The crystals were produced in atmosphere of $\mathrm{Ar}$ with $3 \mathrm{~N}$ or $5 \mathrm{~N}$ purity. The raw materials were prepared from $\mathrm{Al}_{2} \mathrm{O}_{3}$ and $\mathrm{Y}_{2} \mathrm{O}_{3}$ powders with $\mathbf{9 9 . 9 9} \%$ purity mixed in stoichiometric composition. Owing to low apparent density of YAG the loading of the crucible was proceeded in two stages.

The growth rate was $1-3 \mathrm{~mm} / \mathrm{h}$; the crystal rotation rate was $8-10 \mathrm{rot} / \mathrm{min}$.

To compare optical properties of the crystals grown in Mo and Ir, the YAG crystal was grown by the Czochralksi method from Ir crucible with diameter $60 \mathrm{~mm}$ and height $60 \mathrm{~mm}$. Heat insulation made of zircon oxide and alumina was used. Post growth annealing of the crystals was carried out during $96 \mathrm{~h}$ at $1200^{\circ} \mathrm{C}$ in air.

Microphotographs were made using JSM $6390 \mathrm{LV} X$ scanning electron microscope with a $\mathrm{MAX}^{\mathrm{N}} \mathrm{X}$-ray microanalysis system. Admixture content in the crystals was controlled using ICAP 6300 Duo ICP atomic emission spectrometer. Optical absorption spectra of the samples $10 \times 10 \times 1 \mathrm{~mm}^{3}$ with polished faces taken from different parts of the grown crystal were measured using "Specord 40" spectrophotometer.

\section{Results}

Experiments on heating of the Mo crucibles showed that presence of the residual oxygen in the growth atmosphere leads to interaction of Mo with $\mathrm{O}_{2}$ and formation of volatile oxides. They deposit at the zircon ceramics and enter its pores. As a result the ceramics becomes brittle and cracks. 


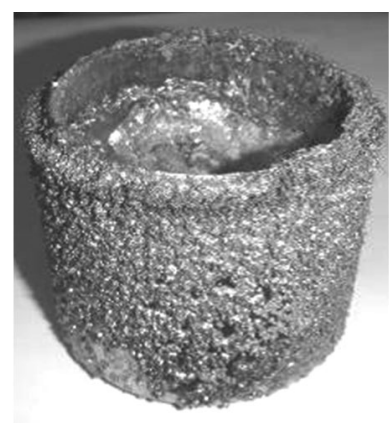

a)

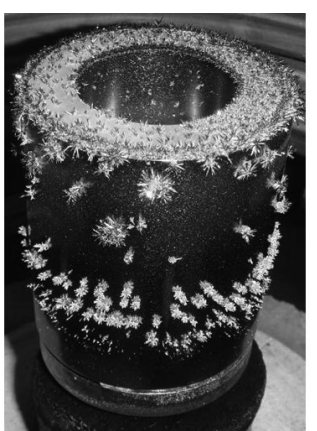

b)
Fig. 1. Crucible side surface covered with Mo needles.

Interaction of the residual oxygen with Mo at temperatures of $500-600^{\circ} \mathrm{C}$ can be illustrated by the equation

$$
2 \mathrm{Mo}+\mathrm{O}_{2}=2 \mathrm{MoO}_{2} \text {. }
$$

Starting from $1200^{\circ} \mathrm{C}$ the needle-like metallic dendrites are formed with the length $2-5 \mathrm{~mm}$ at the most heated side crucible walls (Fig. 1, 2). Needle formation can be attributed to the gas transport reaction

$$
3 \mathrm{MoO}_{2(\mathrm{~s})} \longleftrightarrow 2 \mathrm{MoO}_{3(\mathrm{~g})}+\mathrm{Mo}_{(\mathrm{s})} \cdot
$$

This means that at high temperature $\left(>1200^{\circ} \mathrm{C}\right)$ the gaseous $\mathrm{MoO}_{2}$ decomposes into gaseous $\mathrm{MoO}_{3}$ and metallic Mo, which crystallizes at outer surface of the Mo crucible and inner surface of the zircon ceramics. To prevent Mo from the oxidation, argon was preliminary purified using heated copper and magnesium as the oxygen absorbers. However, heating of the crucible up to the YAG melting temperature showed that oxygen remains in camera and molybdenum oxidizes, though in a lesser degree. Using of super-pure $\operatorname{Ar}(5 \mathrm{~N})$ did not give any positive result. Molybdenum oxides still dissolved in the melt and contaminated it. The dissolved Mo concentration reached 1 wt. $\%$.

Molybdenum oxidation was successfully minimized only in the weakly reducing atmosphere created by substitution of the part of zircon ceramics in the thermal construction by graphite. It prevented from oxidation the lower part of the crucible. Meanwhile the crucible surface located beyond the graphite remained oxidized and covered with the needles (Fig. 1b).

Only complete substitution of the inner layer of heat insulating ceramics with graphite provided protection of the crucible surface from oxidation during heating the crucible and YAG growth. The crucible re-

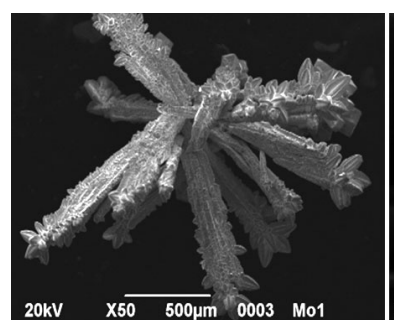

a)

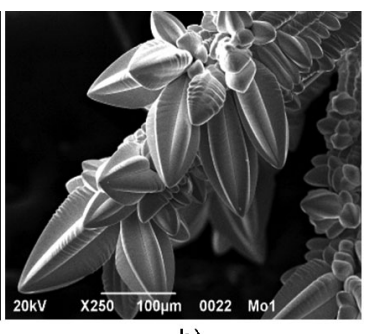

b)

Fig. 2. Needles of metallic Mo.

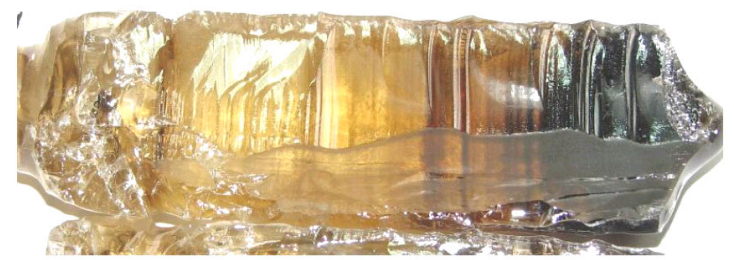

\begin{tabular}{|l|l|l|l|l|l|l|l|l|l|l|}
\hline MM & 10 & 20 & 30 & 40 & 50 & 60 & 70 & 80 & 90 & 100 \\
\hline
\end{tabular}

Fig. 3. YAG crystal grown in the optimized conditions.

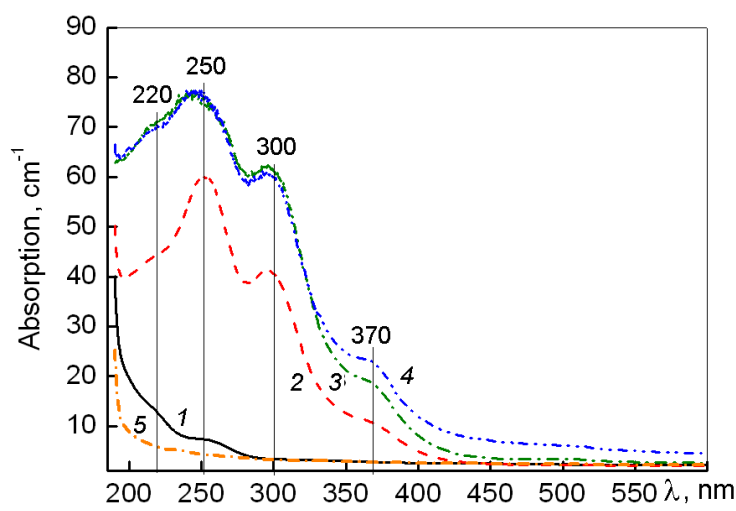

Fig. 4. Absorption spectra of YAG crystals grown in Ir crucible in weakly oxidizing atmosphere (1) and in Mo crucible in the reducing atmosphere (2-5) cut from different distances from the seeding place: $2-l=45 \mathrm{~mm}$, $3-l=100 \mathrm{~mm}, 4-l=130 \mathrm{~mm}, 5-$ sample 2 after annealing in air.

mained intact at heating up to 1900$2000^{\circ} \mathrm{C}$. The YAG crystal with $35 \mathrm{~mm}$ diameter grown in such conditions was yellowbrown with the distinctive layers of inclusions, especially in the lower part (Fig. 3).

Absorption spectra of samples cut from the different parts of the crystals are presented in Fig. 4. For comparison, the absorption spectrum of YAG grown from Ir crucible using the same raw material is presented as well. Intensive bands peaked at $250,300,370 \mathrm{~nm}$ are observed at the spectra of the samples from the crystal grown in Mo. Absorption intensity rises in the 
Table. Content of some admixtures in crystals grown from the Mo crucible

\begin{tabular}{||c|c|c|c|c|c|c|c|c||}
\hline \hline wt. $\%$ & $\mathrm{Fe}$ & $\mathrm{Si}$ & $\mathrm{Mg}$ & $\mathrm{Cu}$ & $\mathrm{Ni}, \mathrm{Bi}, \mathrm{Ti}$ & $\mathrm{Pb}, \mathrm{Cr}, \mathrm{Sn}$ & $\mathrm{Mn}$ & $\mathrm{Mo}$ \\
\hline YAG:Ir & 0.0005 & 0.001 & 0.0001 & 0.0001 & 0.0001 & 0.0001 & 0.0005 & 0.0001 \\
YAG:Mo & 0.0005 & 0.001 & 0.00008 & 0.0001 & 0.0001 & 0.0001 & 0.0005 & 0.002 \\
\hline
\end{tabular}

samples cut from the bottom of the crystal (curves 2, 3, 4). Annealing of sample 2 in air eliminates the coloration and improves the transmission in UV band (curve 5). Absorption of the annealed crystal in UV is even better than in the sample grown in Ir crucible.

Since the same raw materials were used in cases of Ir and Mo crucibles, only the admixture content of Mo and Ir in crystals may differ. Atomic emission analysis shows that content of some cationic admixtures in the crystal does not exceed $1 \cdot 10^{-3}$ wt. $\%$ (Table).

Mo concentration in the crystal was in the range of $0.1 \div 2 \cdot 10^{-3}$ wt. $\%$. Since Mo does not oxidize in the reducing atmosphere, the elevated Mo content may be described by oxidative properties of YAG melt. The YAG melt oxidize Mo, which then enters the crystal. Nevertheless, Mo in the specified concentration does not affect significantly the YAG optical properties. It is worth to note that no Mo effect on the optical properties was mentioned as well in $[1,2]$. Precise determination of carbon content in the oxide compounds is a very difficult task. However, we assume that carbon admixture is the cause of the crystal coloration.

Therefore Mo crucibles can be used at growth of high quality YAG crystals in the reducing atmosphere. However, the Mo crucibles can not be used in thermal construction with graphite heat insulation at overheating of the crucible walls above $2200^{\circ} \mathrm{C}$, because of carbidization of Mo and formation of MoC-Mo eutectics melting at $2200^{\circ} \mathrm{C}$ [1]. Overheating leads to softening and destruction of the crucible surface (Fig. 5) reducing the crucible lifetime.

\section{Conclusions}

High quality YAG crystals can be obtained in Mo crucibles when the growth conditions preventing the oxidation of molybdenum are created. The crucible overheating above $2200^{\circ} \mathrm{C}$ should be avoided to prevent its destruction. Using of zircon ceramics for heat insulation of the Mo crucible is not

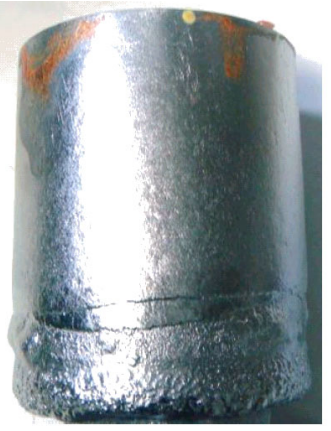

Fig. 5. Destruction of the crucible surface due to carbidization.

permitted, because it is potential origin of oxygen. The crystals must be grown in vacuum or the reducing atmosphere, which can be created, for example, by using graphite heat insulation.

YAG crystal grown in Mo crucibles and annealed in the optimized conditions demonstrates lower optical absorption in UV band than that in the crystals grown in Ir crucibles using the same raw material.

\section{References}

1. Ji.Kvapil, Jo.Kvapil, B.Manek et al., J.Cryst. Growth, 52, 542 (1981).

2. Y.Dong, G.Zhou, J.Xu et al., Mat.Res.Bulletin, 41, 1959 (2006).

3. S.Nizhankovsky, A.Dan'ko, V.Puzikov et al., Functional Materials, 15, 543 (2008).

4. J.Willis, M.Dixon, J.Cryst.Growth, 3, 236 (1968)

5. N.Anisimov, S.Baryshev, A.Gomenyuk et al., J.App. Spectr., 25, 1320 (1976).

6. M.Putilin, Y.Beljakova, V.Golenko, Sintez Mineralov, v.2, Nedra, Moscow (1987) [in Russian].

7. Z.Galazka, D.Schwabe, H.Wilke et al., Cryst. Res. Technol., 38, 859 (2003).

8. G.Zhao, X.Zeng, C.Xia et al., Cryst.Growth, 267, 522 (2004).

9. M.Yadegari, M.Asadian, H.Saeedi et al., $J$. Cryst. Growth, 367, 57 (2013).

10. W.Xiang,J.Zhong, Y.Zhao et al., J.Alloys and Comp., 542, 218 (2012).

11. D.Kostomarov, H.Bagdasarov, S.Kobzeva et al., Kristallografiya, 54, 688 (2009).

12. D.Kostomarov, H.Bagdasarov, S.Kobzeva et al., Kristallografiya, 53, 699 (2008). 